Int Arch Allergy Immunol 1996;110:162

\title{
Announcement
}

\section{Stress of Life}

Stress and Adaptation from Molecules to Man

International Congress of Stress, an interdisciplinary discussion commemorating the 90th birthday of Hans Selye July 1-5,1997, Budapest, Hungary

The aim of this meeting is to provide a stimulating environment for understanding and discussion between scientists from various aspects of stress-related research. The meeting will, therefore, focus on comprehensive plenary lectures (summarizing the major trends of research in the particular field and emphasizing the possible links with others) and related workshops. Poster presentations are also planned.

Conference topics:

Molecular aspects of stress syndrome

Stress adaptation of membranes

Cellular stress in prokaryotes

Cellular stress in eukaryotes

Stress in plants

Stress in animals and men

Biopsychosocial aspects of human stress

Methods of stress-related research

International Scientific Advisory Board:

Ad Appels, István Berczi, Graham D. Burrows, George P. Chrou-sos, Giovanni Cizza, Tibor Farkas, Costa Georgopoulos, John Gruze-lier, Michael Karin, Zoltán Király, Arisztid Kovách, Piet Kuiper, Herman Lips, Richard Morimoto, Paul J. Rosch, János Salánki, Andrew Steptoe, Sándor Szabó, Szilveszter E. Vizi

Organizing Committee:

Lóránd Bertók, Peter Csermely, László Erdei, Sándor Györgyi, Mark Kollai, Maria Kopp, Emil Monos, Judit Szelényi, Zoltán Szigeti, Mihály Szilágyi, Ernö Tyihák, László Vígh

For further information please contact the conference secretariat:

Dr. Peter Csermely Institute of Biochemistry I Semmelweis University PO Box 260 H-1444

Budapest (Hungary)

Phone/Fax: +361-266-6550 E-Mail: stress@puskin.sote.hu

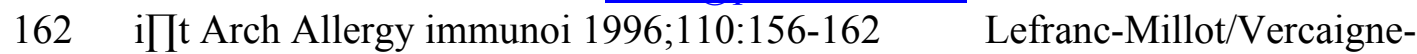

Marko/Wal/

Leprêtre/Peltre/Dhulster/Guillochon 